\title{
Approaches of climate factors affecting the spatial variation of annual gross primary productivity among terrestrial ecosystems in China
}

\author{
Xian-Jin Zhu ${ }^{\mathrm{a}}$, Gui-Rui Yu ${ }^{\mathrm{a}, *}$, Qiu-Feng Wang ${ }^{\mathrm{a}}$, Yan-Ni Gao ${ }^{\mathrm{b}}$, Hong-Lin He ${ }^{\mathrm{a}}$, Han Zheng ${ }^{\mathrm{a}, \mathrm{c}}$, \\ Zhi Chen ${ }^{\mathrm{a}, \mathrm{c}}$, Pei-Li Shi ${ }^{\mathrm{a}}$, Liang Zhao ${ }^{\mathrm{d}}$, Ying-Nian Li $^{\mathrm{d}}$, Yan-Fen Wang ${ }^{\mathrm{c}}$, Yi-Ping Zhang ${ }^{\mathrm{e}}$, \\ Jun-Hua Yan ${ }^{\mathrm{f}}$, Hui-Min Wang ${ }^{\mathrm{a}}$, Feng-Hua Zhao ${ }^{\mathrm{a}}$, Jun-Hui Zhang ${ }^{\mathrm{g}}$ \\ a Synthesis Research Center of Chinese Ecosystem Research Network, Key Laboratory of Ecosystem Network Observation and Modeling, \\ Institute of Geographic Sciences and Natural Resources Research, Chinese Academy of Sciences, Beijing 100101, China \\ ${ }^{\mathrm{b}}$ State Key Laboratory of Environmental Criteria and Risk Assessment, Chinese Research Academy of Environmental Sciences, Beijing 100012, China \\ c University of Chinese Academy of Sciences, Beijing 100049, China \\ ${ }^{\mathrm{d}}$ Northwest Institute of Plateau Biology, Chinese Academy of Sciences, Xining 810001, China \\ e Key Lab of Tropical Forest Ecology, Xishuangbanna Tropical Botanical Garden, Chinese Academy of Sciences, Menglun 666303, China \\ ${ }^{\mathrm{f}}$ South China Botanical Garden, Chinese Academy of Sciences, Guangzhou 510650, China \\ ${ }^{\mathrm{g}}$ Institute of Applied Ecology, Chinese Academy of Sciences, Shenyang 110016, China
}

\section{A R T I C L E I N F O}

\section{Article history:}

Received 12 February 2015

Received in revised form 14 August 2015

Accepted 13 November 2015

Available online 14 December 2015

\section{Keywords:}

Gross primary productivity

Eddy covariance

Annual mean air temperature

Annual precipitation

Carbon cycle

Terrestrial ecosystems

Radiation use efficiency

$\mathrm{CO}_{2}$ mass concentration

\begin{abstract}
A B S T R A C T
Analyzing the approaches that climatic factors affect the spatial variation of annual gross primary productivity $\left(\mathrm{GPP}_{\mathrm{yr}}\right)$ would improve our understanding on its spatial pattern. Based on network eddy covariance measurements and published data in literature, we separated GPP $\mathrm{yr}_{\mathrm{yr}}$ into radiation use efficiency (RUE) and annual absorbed photosynthesis active radiation $\left(A P A R_{y r}\right)$, where $A P A R_{y r}$ can be regarded as the product of the fraction of absorbed annual photosynthesis active radiation $\left(\mathrm{FPAR}_{\mathrm{yr}}\right)$ and annual PAR (PAR $\mathrm{Pr}_{\mathrm{yr}}$ ). Given that PAR $_{\mathrm{yr}}$ affects the spatial variation of $\mathrm{GPP}_{\mathrm{yr}}$ directly through itself, we investigated factors affecting the spatial variations of RUE and $\mathrm{FPAR}_{\mathrm{yr}}$, to reveal how climatic factors affect the spatial varia-

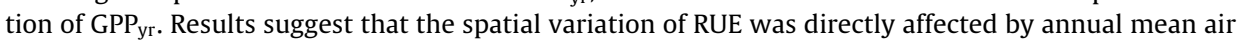
temperature (MAT) and annual mean $\mathrm{CO}_{2}$ mass concentration $\left(\rho_{\mathrm{cyr}}\right)$. The increasing MAT and $\rho_{\text {cyr }}$ directly enhanced RUE. The increasing annual precipitation (MAP) directly prompted FPAR yr $_{\text {. Therefore, MAT and }}$

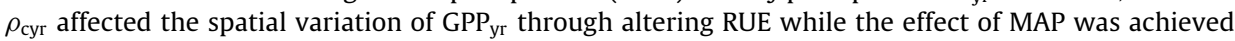
through altering FPAR $_{\mathrm{yr}}$. Our study could also provide an alternative way for regional GPP $\mathrm{ys}_{\mathrm{yr}}$ assment.
\end{abstract} (c) 2015 Elsevier Ltd. All rights reserved.

\section{Introduction}

Gross primary productivity (GPP) is the amount of $\mathrm{CO}_{2}$ that is taken up by plants from the atmosphere through photosynthesis (Chen et al., 2012), serving as the largest carbon flux between terrestrial ecosystems and the atmosphere (Beer et al., 2010). Along with ecosystem respiration, GPP controls the $\mathrm{CO}_{2}$ exchange between terrestrial ecosystems and the atmosphere (Beer et al., 2010), which is of significant importance in regulating the terrestrial carbon budget (Chapin et al., 2006; Yuan et al., 2010) and then

\footnotetext{
* Corresponding author at: Institute of Geographic Sciences and Natural Resources Research, Chinese Academy of Sciences, 11A Datun Road, Chaoyang District, Beijing 100101, China. Tel.: +86 10 64889432; fax: +86 1064889432 .

E-mail address: yugr@igsnrr.ac.cn (G.-R. Yu).
}

climate change (Ciais et al., 2013; Hilker et al., 2008; Li et al., 2013). Additionally, as the start of biogeochemical cycles, GPP drives several ecosystem functions (Beer et al., 2010) and contributes to ecosystem services such as food and wood production. Therefore, it is worthwhile to quantify the magnitude of GPP and its spatial variation at the regional scale.

Based on network eddy covariance measurements, many investigations have analyzed the spatial variation of annual GPP (GPPyr) and its affecting factors (Baldocchi, 2008; Chen et al., 2013b; Kato and Tang, 2008; Law et al., 2002; Luyssaert et al., 2007; Wang et al., 2008b; Yu et al., 2013). Many factors, especially climatic variables such as annual mean air temperature (MAT) (Chen et al., 2013b; Kato and Tang, 2008; Luyssaert et al., 2007; Magnani et al., 2007; Reichstein et al., 2007; Yu et al., 2013) and annual precipitation (MAP) (Chen et al., 2013b; Kato and Tang, 2008; Luyssaert et al., 2007; Yu et al., 2013), were found to strongly affect the spatial 


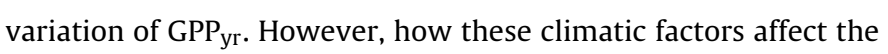
spatial variation of GPP $\mathrm{yr}$ was not well documented, which impeded our fully understanding on the spatial variation of GPPyr.

Radiation use efficiency theory is widely used to describe the dynamics of GPP over the world (Running et al., 2004; Wang et al., 2010; Wu et al., 2010a; Zhao and Running, 2010), which provides a solid basis for revealing how climatic factors affect the spatial variation of $\mathrm{GPP}_{\mathrm{yr}}$. According to the radiation use efficiency theory (Monteith, 1972), GPPyr can be considered as the product of radiation use efficiency (RUE) and absorbed annual photosynthesis active radiation $\left(A P A R_{y r}\right)$, where $A P A R_{y r}$ was the fraction of APAR $_{\mathrm{yr}}\left(\mathrm{FPAR}_{\mathrm{yr}}\right)$ multiplying annual photosynthesis active radiation $\left(\mathrm{PAR}_{\mathrm{yr}}\right)$. Given that $\mathrm{PAR}_{\mathrm{yr}}$ affects the spatial variation of $\mathrm{GPP}_{\mathrm{yr}}$ by itself, analyzing factors affecting the spatial variations of RUE and FPAR $_{\mathrm{yr}}$ would thus underpin our understanding on how factors affect that of $\mathrm{GPP}_{\mathrm{yr}}$. Factors affecting the spatial variation of RUE have been extensively investigated. For example, the spatial variation of RUE was found to be affected by that of MAT (Schwalm et al., 2006) or MAP (Garbulsky et al., 2010), while most of these studies were conducted among European (Garbulsky et al., 2010) or American ecosystems (Schwalm et al., 2006), which covered a limited range of altitude. Though climatic and global change were found to influence the interannual variation of FPAR yr $_{\text {(Ciais et al., }}$ 2005; Nemani et al., 2003), little attention was paid to factors affecting the spatial variation of PPAR $_{\mathrm{yr}}$ as it can be directly calculated from satellite products. Therefore, our current understandings on how climatic factors affect the spatial variation of RUE and $F P A R_{y r}$ thus GPP $\mathrm{yr}_{\mathrm{r}}$ may be insufficient, which impeded our understanding on $\mathrm{GPP}_{\mathrm{yr}}$ spatial variation.

Situated in the eastern of Asia, China experiences a unique climate and huge altitude gradient because of the uplift of QinghaiTibetan Plateau and Asian monsoon (Wu et al., 2007). Therefore, analyzing the spatial variations of RUE and $F P_{\mathrm{yr}}$ in China would help to reveal how various factors affect the global variation of $\mathrm{GPP}_{\mathrm{yr}}$, which would also provide an alternative tool to assess the spatiotemporal variation of $\mathrm{GPP}_{\mathrm{yr}}$, the basis for carbon management policy aiming at mitigating climate change (Houghton, 2007; Piao et al., 2009). Chinese scientists have conducted eddy covariance measurements, which simultaneously measured $\mathrm{CO}_{2}$ fluxes and meteorological variables, for many years (Yu et al., 2013), making it possible to conduct such an analysis.

Therefore, based on radiation use efficiency theory and eddy covariance measurements in China (Fig. 1), we first separated GPP into RUE, FPAR $\mathrm{yr}_{\mathrm{y}}$, and $\mathrm{PAR}_{\mathrm{yr}}$. Then factors affecting the spatial variations of RUE and FPAR $_{\mathrm{yr}}$ were detailed investigated. The specific objectives of our study were to: 1 ) reveal factors affecting the spatial variations of RUE and FPAR $\mathrm{yr}$ in terrestrial ecosystems of China, and 2) further clarify how climatic factors affect the spatial variation of $\mathrm{GPP}_{\mathrm{yr}}$.

\section{Material and methods}

\subsection{Site information}

By integrating ChinaFLUX observations and other measurements in literature, we built a dataset containing 55-site GPP $\mathrm{yr}$ data (Fig. 1). This dataset covered most ecosystem types (Fig. 1) and fully represented the spatial distribution of typical ecosystems in China. The detailed site information was provided in Table 1.

\section{2. $G P P_{y r}$ and climatic data processing}

In this study, $\mathrm{GPP}_{\mathrm{yr}}$ was estimated from eddy covariance measurements, which was collected from literature. When collecting $\mathrm{GPP}_{\mathrm{yr}}$ data, we simultaneously gathered geographical information and main climatic variables, including latitude, longitude, altitude, MAT, MAP, and PAR $\mathrm{yr}_{\mathrm{r}}$, most of which were thought to potentially affect the spatial variation of $\mathrm{GPP}_{\mathrm{yr}}$. If the site missed MAT and MAP, we used its multi-year average as the substitution. If there were no $\mathrm{PAR}_{\mathrm{yr}}$ observations, we obtained its value from the interpolated PAR $_{\text {yr }}$ (Zhu et al., 2010).

In addition, $\mathrm{CO}_{2}$ was found to affect the seasonal and interannual variation of instaneous GPP (Norby et al., 2005). Therefore, we introduced annual mean $\mathrm{CO}_{2}$ mass concentration $\left(\rho_{\text {cyr }}\right)$ as another climatic variable. Given that no $\rho_{\text {cyr }}$ was directly reported at most sites, we calculated $\rho_{\text {cyr }}$ based on the $\mathrm{CO}_{2}$ mole fraction $\left(b_{\mathrm{c}}\right)$ from Mauna Loa (Keeling et al., 1976; Thoning et al., 1989), $\mathrm{CO}_{2}$ mole mass $\left(M_{\mathrm{c}}, 44 \mathrm{~g} \mathrm{~mol}^{-1}\right)$, and mole volume at the current state $\left(V_{1}\right)$ as:

$\rho_{\mathrm{cyr}}=\frac{b_{\mathrm{c}} \times M_{\mathrm{c}}}{V_{1}}$

Where $V_{1}$ can be calculated based on the ideal gas state equation as:

$$
\begin{aligned}
V_{1} & =\frac{P_{0} \times V_{0}}{\left(273.15+T_{a 0}\right)} \times \frac{\left(273.15+T_{a 1}\right)}{P_{1}} \\
& =\frac{101325 \times 22.4 \times 10^{-3}}{298.15} \times \frac{\left(273.15+T_{a 1}\right)}{P_{1}}
\end{aligned}
$$

where $P_{1}$ and $T_{a 1}$ are the atmospheric pressure and MAT at the current state, respectively. While $P_{0}, V_{0}$, and $T_{a 0}$ are the atmosphere pressure, mole volume, and MAT at the normal state, respectively, which equal to $101325 \mathrm{~Pa}, 22.4 \times 10^{-3} \mathrm{~m}^{3} \mathrm{~mol}^{-1}$, and $25^{\circ} \mathrm{C}$, respectively.

According to the pressure-height formula, we calculated $P_{1}$ from altitude (Alt, with the unit of $\mathrm{m}$ ) and MAT (with the unit of ${ }^{\circ} \mathrm{C}$ ) as:

$P_{1}=1013.25 / 10^{\left(\frac{\text { Alt }}{18400 \times\left(1+\frac{\mathrm{MAT}}{273}\right)}\right)}$

In addition, if the site had multiyear observations, we calculated the mean $\mathrm{GPP}_{\mathrm{yr}}$ and climatic variables among the measuring period, which may exclude the effect of inter-annual variation.

\subsection{Leaf area index data processing}

At each site, we extracted LAI data with 8-day temporal resolution from the global land surface satellite dataset (Liang et al., 2013) and calculated the annual mean LAI ( $\mathrm{LAI}_{\mathrm{yr}}$ ) for the year that GPPyr was observed as:

$\mathrm{LAI}_{\mathrm{yr}}=\frac{1}{46} \sum_{\mathrm{i}=1}^{46} \mathrm{LAI}_{\mathrm{i}}$

where $\mathrm{LAI}_{\mathrm{i}}$ is the 8-day LAI values.

If the site had multiyear observations, we also used the mean $\mathrm{LAI}_{\mathrm{yr}}$ for the measuring period to represent its biotic factor.

\subsection{RUE calculation}

According to the radiation use efficiency theory, GPPyr is the product of RUE, FPAR $\mathrm{LAI}_{\mathrm{yr}}$ based on Beer-lambert law as:

$\operatorname{FPAR}_{\mathrm{yr}}=1-\exp \left(-k \times \mathrm{LAI}_{\mathrm{yr}}\right)$

where $k$ is the extinction coefficient, which is set to 0.5 according to Yuan et al. (2010). Therefore, $\mathrm{RUE}\left(\mathrm{gC} \mathrm{MJ}^{-1}\right)$ was calculated as

$\mathrm{RUE}=\frac{\mathrm{GPP}_{\mathrm{yr}}}{\text { FPAR }_{\mathrm{yr}} \times \mathrm{PAR}_{\mathrm{yr}}}$ 
Site information used in this study.

\begin{tabular}{|c|c|c|c|c|c|c|c|c|c|c|}
\hline Observation period & Site code & Latitude $\left({ }^{\circ} \mathrm{N}\right)$ & Longitude $\left({ }^{\circ} \mathrm{E}\right)$ & Altitude (m.a.s.l) & Ecosystem types & IGBP classification $^{1}$ & $\operatorname{MAT}\left({ }^{\circ} \mathrm{C}\right)^{2}$ & $\operatorname{MAP}(\mathrm{mm})$ & $\operatorname{GPP}_{\mathrm{yr}}\left(\mathrm{gCm}^{-2} \mathrm{yr}^{-1}\right)$ & Reference \\
\hline 2003-2008 & XSBN & 21.95 & 101.20 & 750 & Forest & $\mathrm{EBF}$ & $19.25 \pm 0.23$ & $1416.75 \pm 201.09$ & $2342.67 \pm 174.10$ & (Zhang et al., 2010) \\
\hline $2003-2008$ & DHS & 23.17 & 112.53 & 300 & Forest & MF & $20.37 \pm 0.32$ & $1481.67 \pm 353.56$ & $1367.26 \pm 78.42$ & ChinaFLUX \\
\hline 2009-2010 & ALS & 24.53 & 101.02 & 2476 & Forest & EBF & 11.63 & 1374.4 & 1848.34 & (Tan et al., 2011) \\
\hline $2003-2008$ & QYZ & 26.73 & 115.05 & 100 & Forest & $\mathrm{EBF}$ & $18.19 \pm 0.41$ & $1094.03 \pm 204.91$ & $1798.74 \pm 100.44$ & ChinaFLUX \\
\hline 2008 & HT & 26.83 & 109.75 & 330 & Forest & ENF & 16.8 & 1214.9 & 1272 & (Zhang, 2010) \\
\hline 2003 & TY & 28.92 & 111.45 & 92 & Cropland & CRO & 17 & 1050 & 1598.54 & (Zhu, 2005) \\
\hline 2006-2007 & YY & 29.53 & 112.86 & 30 & Forest & EBF & 17.85 & 1502.99 & 1974.8 & (Han, 2008) \\
\hline $2004-2008$ & DX & 29.67 & 91.33 & 4250 & Grassland & GRA & $2.51 \pm 0.49$ & $468.44 \pm 155.61$ & $197.47 \pm 58.14$ & ChinaFLUX \\
\hline 2006-2007 & $\mathrm{AQ}$ & 30.47 & 116.99 & 10 & Forest & $\mathrm{EBF}$ & 17.41 & 1500 & 1859.2 & (Han, 2008) \\
\hline 2005-2007 & DTG & 31.52 & 121.96 & 4 & Wetland & WET & $16.33 \pm 0.47$ & $864.67 \pm 50.16$ & $1829.67 \pm 193.54$ & (Guo, 2010a) \\
\hline $2005-2007$ & DTD & 31.52 & 121.97 & 4 & Wetland & WET & $16.33 \pm 0.47$ & $864.67 \pm 50.16$ & $1570 \pm 218.09$ & (Guo, 2010a) \\
\hline 2005 & DTZ & 31.58 & 121.90 & 4 & Wetland & WET & 15.56 & 817 & 1512.63 & FLUXNET \\
\hline 2010 & $\mathrm{XP}$ & 33.35 & 113.91 & 49 & Forest & DBF & 14.8 & 529.5 & 1288.1 & (Geng, 2011) \\
\hline 2006 & SJY & 34.35 & 100.55 & 3980 & Grassland & GRA & -2 & 461 & 480.27 & (Wu et al., 2010b) \\
\hline 2007-2008 & WS & 36.65 & 116.05 & 30 & Cropland & CRO & 13.45 & 470.55 & 1838 & (Lei and Yang, 2010) \\
\hline 2003-2008 & YC & 36.83 & 116.57 & 28 & Cropland & CRO & $12.91 \pm 0.78$ & $575.35 \pm 174.75$ & $1746.62 \pm 139.35$ & ChinaFLUX \\
\hline $2002-2004$ & $\mathrm{HB}$ & 37.62 & 101.30 & 3250 & Grassland & GRA & $-1.03 \pm 0.45$ & $609.37 \pm 31.47$ & $634.5 \pm 54.15$ & (Kato et al., 2006) \\
\hline $2003-2008$ & HBGC & 37.67 & 101.33 & 3293 & Grassland & GRA & $-1.77 \pm 0.74$ & $473.9 \pm 65.45$ & $574.64 \pm 45.22$ & ChinaFLUX \\
\hline 2004-2008 & HBSD & 37.68 & 101.31 & 3160 & Wetland & WET & $-1.35 \pm 0.49$ & $438.9 \pm 110.40$ & $489.12 \pm 40.61$ & ChinaFLUX \\
\hline 2006 & DXF & 39.53 & 116.25 & 30 & Forest & DBF & 11.5 & 444.2 & 1525 & (Zha, 2007) \\
\hline 2006 & KBQG & 40.38 & 108.55 & 1170 & Grassland & GRA & 7.5 & 180 & 270.18 & FLUXNET \\
\hline $2005-2006$ & $\mathrm{KBQF}$ & 40.54 & 108.69 & 1020 & Forest & DBF & 9.38 & 153.06 & 162.78 & FLUXNET \\
\hline 2005 & PJ & 41.13 & 121.90 & 7 & Wetland & WET & 8.97 & 590 & 1298.16 & (Zhou et al., 2009) \\
\hline 2005-2006 & DLC & 42.05 & 116.67 & 1350 & Cropland & CRO & 3.02 & 411.4 & 306.76 & (Zhang et al., 2007) \\
\hline 2005-2006 & DLG & 42.05 & 116.28 & 1350 & Grassland & GRA & 2.77 & 550.08 & 324.16 & (Zhang et al., 2007) \\
\hline $2003-2008$ & CBS & 42.40 & 128.10 & 736 & Forest & MF & $4.42 \pm 0.57$ & $465.65 \pm 35.78$ & $1338.84 \pm 108.86$ & ChinaFLUX \\
\hline 2006 & XLF & 43.55 & 116.67 & 1250 & Grassland & GRA & 1.45 & 202 & 148.71 & (Chen et al., 2009), FLUXNET \\
\hline 2006 & XLD & 43.55 & 116.67 & 1250 & Grassland & GRA & 1.51 & 202 & 294.45 & (Chen et al., 2009), FLUXNET \\
\hline 2004-2006 & XLHT & 44.13 & 116.33 & 1030 & Grassland & GRA & $1.9 \pm 1.49$ & $241.67 \pm 63.07$ & $130.02 \pm 25.53$ & (Wang et al., 2008c) \\
\hline 2004-2006 & FK & 44.28 & 87.93 & 475 & Grassland & GRA & 6.5 & $153.23 \pm 23.25$ & $218.25 \pm 125.49$ & (Liu et al., 2012) \\
\hline $2004-2008$ & NM & 44.53 & 116.67 & 1189 & Grassland & GRA & $1.16 \pm 1.24$ & $252.46 \pm 89.25$ & $231.66 \pm 111.13$ & ChinaFLUX \\
\hline 2004-2006 & TYC & 44.57 & 122.92 & 159 & Cropland & CRO & 6.37 & 311.7 & $444.33 \pm 56.36$ & (Du et al., 2012) \\
\hline 2007-2008 & $\mathrm{CL}$ & 44.58 & 123.50 & 150 & Grassland & GRA & 7.5 & 296.05 & 488.15 & (Dong et al., 2011) \\
\hline 2004-2006 & TYG & 44.59 & 122.52 & 168 & Grassland & GRA & 6.37 & 311.7 & $304.67 \pm 22.81$ & (Du et al., 2012) \\
\hline 2004 & LS & 45.33 & 127.67 & 340 & Forest & DNF & 1.79 & 552 & 1351 & (Wang et al., 2008a) \\
\hline 2004 & MES & 45.42 & 127.67 & 340 & Forest & $\mathrm{DBF}$ & 2.8 & 772.9 & 1176 & (Wang, 2008) \\
\hline 2004-2006 & SJS & 47.58 & 133.52 & 56 & Wetland & WET & 2 & 549.33 & 497 & (Song, 2007) \\
\hline 2006 & SJD & 47.58 & 133.52 & 56 & Cropland & CRO & 2 & 544 & 689 & (Song, 2007) \\
\hline 2006 & SJC & 47.58 & 133.52 & 56 & Cropland & CRO & 2 & 544 & 568 & (Song, 2007) \\
\hline $2007-2008$ & $\mathrm{HZ}$ & 51.78 & 123.02 & 773 & Forest & DNF & -4.4 & 655 & 739.03 & ChinaFLUX \\
\hline 2008-2009 & REG & 33.93 & 102.87 & 3430 & Wetland & WET & 1.1 & 650 & 630.95 & (Hao et al., 2011) \\
\hline 2010 & $\mathrm{GQ}$ & 21.57 & 109.76 & 0 & Wetland & WET & 22.9 & 1770 & 1952.6 & (Chen, 2013; Xiao et al., 2013) \\
\hline 2009-2011 & YX & 23.92 & 117.42 & 65 & Wetland & WET & 21.3 & $992.57 \pm 99.51$ & $1855.33 \pm 84.24$ & (Chen, 2013; Xiao et al., 2013) \\
\hline 2011 & LA & 30.18 & 119.34 & 185 & Forest & EBF & 16 & 1201.72 & 1235.15 & (Sun et al., 2013) \\
\hline 2005 & $\mathrm{HN}$ & 33.00 & 117.00 & 15 & Forest & DBF & 17.68 & 1500 & 1700.94 & FLUXNET \\
\hline 2008 & YK & 38.86 & 100.41 & 1519 & Cropland & CRO & 7 & 67.4 & 1567 & (Wang et al., 2012) \\
\hline $2007-2009$ & XLD & 35.020 & 112.47 & 410 & Forest & $\mathrm{DBF}$ & $15.08 \pm 0.35$ & $395.4 \pm 95.22$ & $1332.14 \pm 44.18$ & (Guo, 2010b) \\
\hline $2009-2010$ & DG & 22.97 & 113.74 & 40 & Forest & EBF & 22.7 & 2033.5 & 1482 & (Sun et al., 2012) \\
\hline $2007-2008$ & HG & 35.95 & 104.13 & 1961 & Grassland & GRA & 8.3 & 250 & 204 & (Du et al., 2012) \\
\hline $2006-2009$ & $\mathrm{JFL}$ & 18.61 & 108.84 & 890 & Forest & $\mathrm{EBF}$ & 19.8 & 2348.75 & 1970 & (Chen, 2010) \\
\hline 2011 & $\mathrm{AJ}$ & 30.48 & 119.67 & 380 & Forest & EBF & 14 & 1518.8 & 1595 & (Yang, 2012) \\
\hline 2010 & HY & 36.95 & 100.75 & 3140 & Grassland & GRA & 1 & 354.2 & 611.43 & (Zhang et al., 2012) \\
\hline 2008 & AR & 38.04 & 100.46 & 3032 & Grassland & GRA & -0.67 & 450 & 853 & (Wang et al., 2012) \\
\hline 2012 & BDL & 40.37 & 115.94 & 535 & Forest & DBF & 8.6 & 354.4 & 694 & (Tang et al., 2013) \\
\hline 2012 & ALP & 40.02 & 116.38 & 51 & Forest & DBF & 10.8 & 716 & 1192 & (Chen et al., 2013a) \\
\hline
\end{tabular}

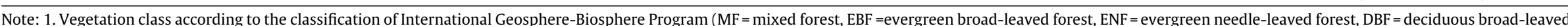
forest, $\mathrm{DNF}=$ deciduous needle-leaved forest, $\mathrm{GRA}=$ grassland, $\mathrm{OSH}=$ open shrubland, $\mathrm{CRO}=$ cropland, WET = wetland $)$.

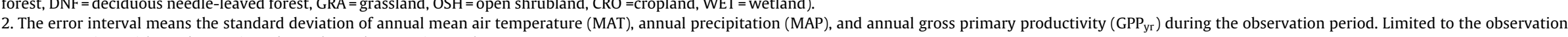
years, some sites with $<3$ observations do not have the error interval. 


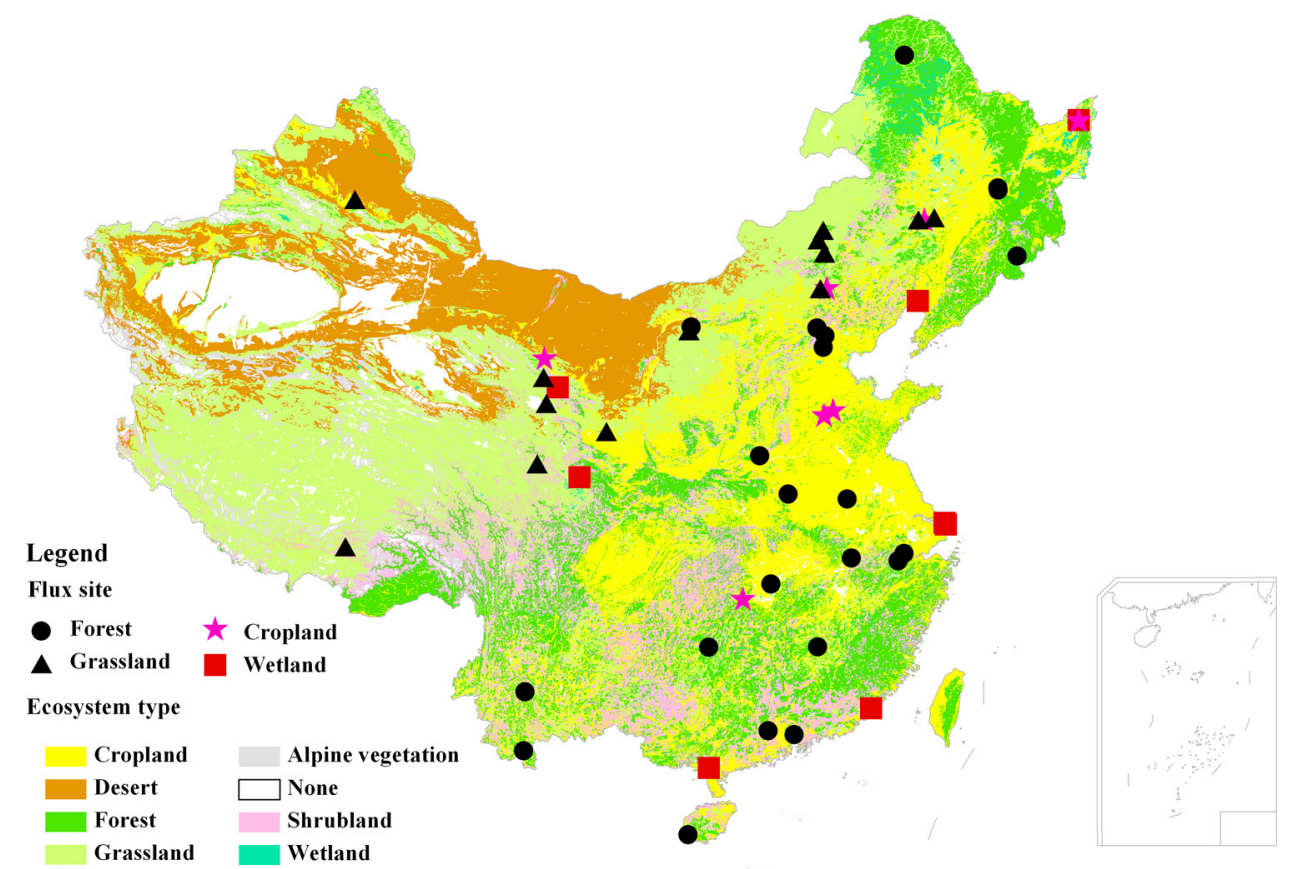

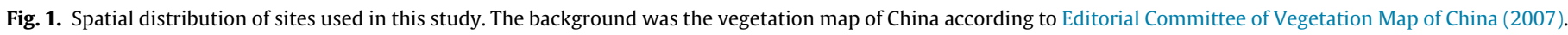

\subsection{Statistical analyses}

Under Matlab 7.7 (Math Works Inc., Natick, MA, USA), we employed the linear regression to separately analyze the effects of various factors such as MAT, MAP, PAR $\mathrm{yr}, \rho_{\mathrm{cyr}}$, and $\mathrm{LAI}_{\mathrm{yr}}$ on the spatial variations of RUE and $F_{P A R}$, respectively. Based on the significant factors, the stepwise regression was used to build a multivariable regression. Path analysis was then explored to distinguish the direct factors affecting the spatial variation of RUE.

\section{Results}

\subsection{Factors affecting the spatial variation of RUE}

Many factors were found to significantly affect the spatial variation of RUE but their effects distinctly differed (Fig. 2). MAT, whose increase significantly raised RUE, inserted the strongest effect on the spatial variation of RUE, with an $R^{2}$ of 0.35 and an RMSE of $0.69 \mathrm{gC} \mathrm{MJ}^{-1}$ (Fig. 2a), while MAP played the weakest role in the spatial variation of RUE, only $10 \%$ of which was explained (Fig. 2 b).

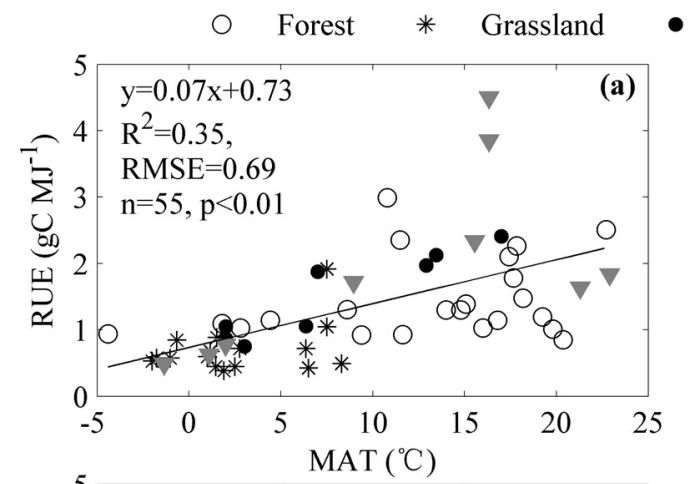

- Cropland $\nabla$ Wetland
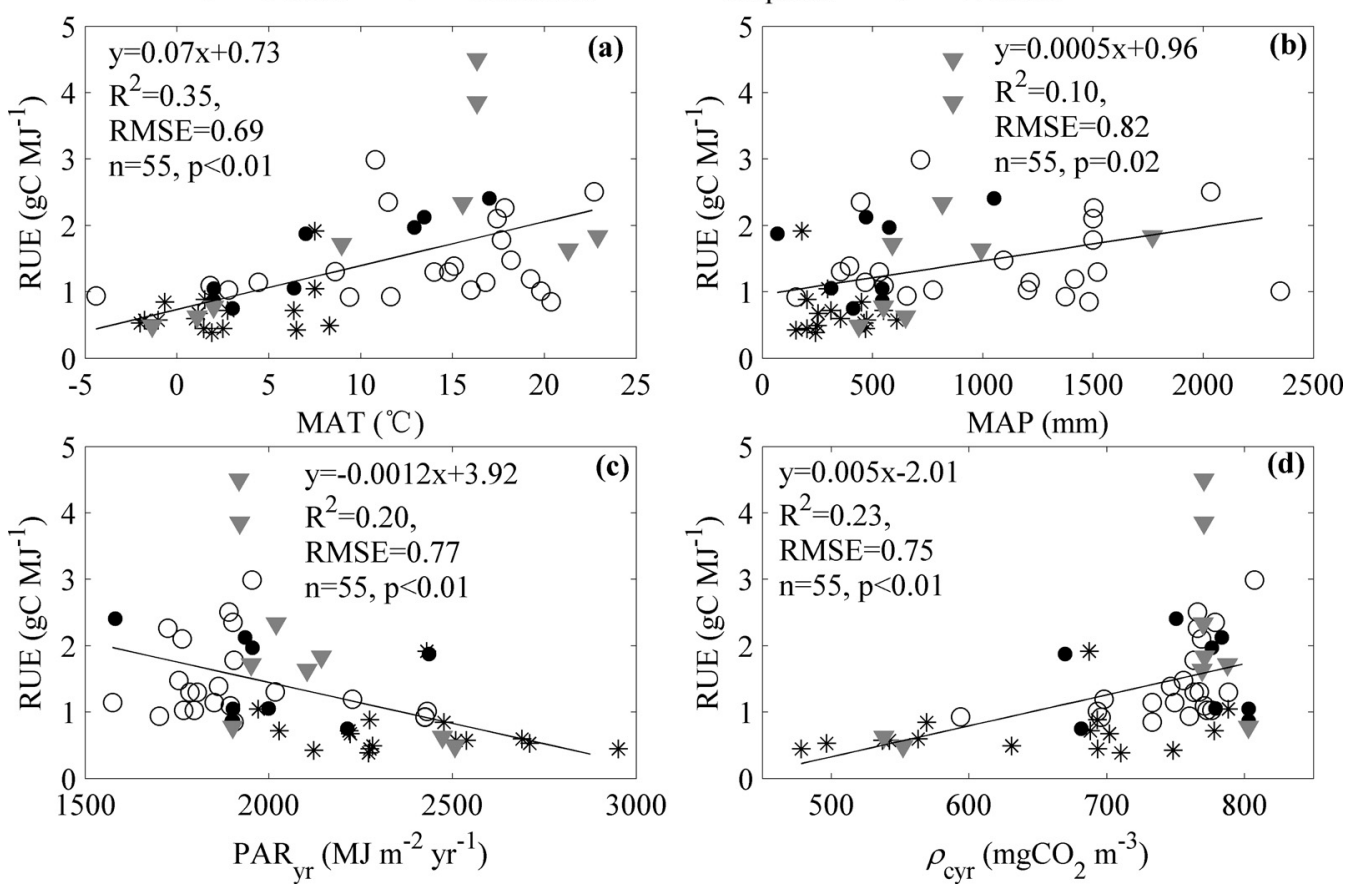

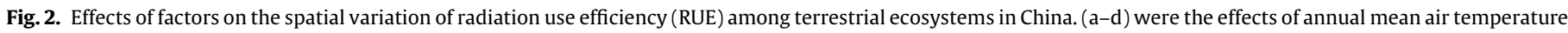
(MAT, a), annual precipitation (MAP, b), annual photosynthesis active radiation ( $\left.\mathrm{PAR}_{\mathrm{yr}}, \mathrm{c}\right)$, and annual mean $\mathrm{CO}_{2}$ mass concentration $\left(\rho_{\mathrm{cyr}}, \mathrm{d}\right)$, respectively. 


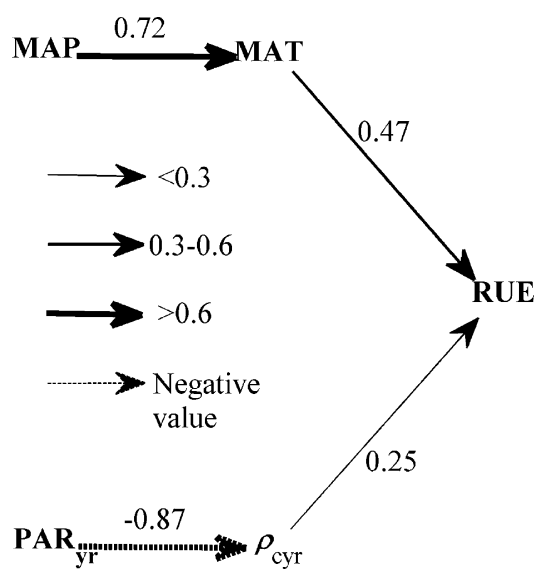

Fig. 3. Path diagram of factors affecting the spatial variation of radiation use efficiency (RUE). The abbreviations of factors were as follows: annual mean air temperature (MAT), annual precipitation (MAP), annual photosynthesis active radiation $\left(\mathrm{PAR}_{\mathrm{yr}}\right)$, and annual mean $\mathrm{CO}_{2}$ mass concentration $\left(\rho_{\mathrm{cyr}}\right)$.

$\mathrm{PAR}_{\mathrm{yr}}$ exhibited a negative effect on the spatial variation of RUE, with an $R^{2}$ of 0.20 and an RMSE of $0.77 \mathrm{gC} \mathrm{MJ}^{-1}$ (Fig. 2c), whereas the increasing $\rho_{\text {cyr }}$ significantly prompted RUE, with an $R^{2}$ of 0.23 and an RMSE of $0.75 \mathrm{gC} \mathrm{MJ}^{-1}$ (Fig. 2d). However, there was no significant correlation between $\mathrm{LAI}_{\mathrm{yr}}$ and RUE (data were not shown).

The multivariable regression equation, which was developed from stepwise regression, only contained MAT and $\rho_{\text {cyr }}$ (Eq. 7) and explained $40 \%$ of the spatial variation of RUE, with an RMSE of $0.67 \mathrm{gC} \mathrm{MJ}^{-1}$.

$$
\mathrm{RUE}=0.052 \mathrm{MAT}+0.0024_{\rho \mathrm{cyr}}-0.887
$$$$
R^{2}=0.40, \text { RMSE }=0.67, n=55
$$

Path analysis results validated that the spatial variation of RUE was jointly affected by the direct effects of MAT and $\rho_{\text {cyr }}$ (Fig. 3 ). The increasing MAT and $\rho_{\text {cyr }}$ had positive direct effects on the spatial variation of RUE. In addition, the effect of MAP was reflected by the direct effect of MAT, while that of $\mathrm{PAR}_{\mathrm{yr}}$ was represented by the direct effect of $\rho_{\text {cyr }}$.

\subsection{Factors affecting the spatial variation of FPAR ${ }_{y r}$}

The spatial variation of $\mathrm{FPAR}_{\mathrm{yr}}$ was also found to be affected by many factors (Fig. 4). The increasing MAT prompted PPAR $_{\mathrm{yr}}$ in spatial, with an $R^{2}$ of 0.19 and an RMSE of 0.19 . MAP, whose increase enhanced FPAR $\mathrm{yr}$, served as the strongest climatic factor affecting the spatial variation of FPAR $\mathrm{R}_{\mathrm{yr}}$, with an $R^{2}$ of 0.43 and an RMSE of 0.16 (Fig. 4b). However, with the increasing $\mathrm{PAR}_{\mathrm{yr}}, \mathrm{FPAR}_{\mathrm{yr}}$ exhibited a decreasing trend (Fig. 4c).

The developed regression equation by the stepwise regression just contained MAP, suggesting that the spatial variation of $\mathrm{FPAR}_{\mathrm{yr}}$ sourced from the direct effect of MAP.

In addition, $\mathrm{FPAR}_{\mathrm{yr}}$ was the function of $\mathrm{LAI}_{\mathrm{yr}}$ (Eq. 5), whose spatial variation was primarily affected by the direct effect of MAP (Supplementary Material 1). Therefore, MAP affected the spatial variation of FPAR $\mathrm{yr}_{\mathrm{yr}}$ through altering $\mathrm{LAI}_{\mathrm{yr}}$.

\subsection{Approaches of climatic factors affecting the spatial variation of GPPyr}

Based on above analyses, we can infer the approaches that climatic factors affect the spatial variation of GPP $\mathrm{yr}$ in China (Fig. 5). $\mathrm{GPP}_{\mathrm{yr}}$ was the product of RUE, FPAR $\mathrm{yr}$, and $\mathrm{PAR}_{\mathrm{yr}}$. The spatial variation of RUE was controlled by the joint effects of MAT and $\rho_{\mathrm{cyr}}$, whose increase made RUE significantly increase (Fig. 5a and 5b) The spatial variation of FPAR $R_{y r}$ was primarily affected by MAP, which dominated the spatial variation of LAI (Fig. 5c), the foundation for calculating FPAR $_{\mathrm{yr}}$ (Eq. 5). Therefore, MAT and $\rho_{\mathrm{cyr}}$ affected the spatial variation of $\mathrm{GPP}_{\mathrm{yr}}$ primarily by altering RUE, while the effect of MAP was primarily achieved through altering FPAR $_{\mathrm{yr}}$.

\section{Discussion}

\subsection{Mechanisms underlying how climatic factors affect the spatial variation of GPPyr}

Following the radiation use efficiency theory, we separated $G P P_{y r}$ into RUE, FPAR ${ }_{y r}$, and PAR tial variations of RUE and $\mathrm{FPAR}_{\mathrm{yr}}$ were investigated to reveal how climatic factors affect the spatial variation of $\mathrm{GPP}_{\mathrm{yr}}$. However, radiation use efficiency theory is developed from describing daily GPP and deems it as the product of RUE and APAR, where APAR was the multiplication of PAR and FPAR (Running et al., 2004; Wang et al., 2010; Wu et al., 2010a; Zhao and Running, 2010). RUE used in this study differed from that in describing the daily GPP. Therefore, based on the radiation use efficiency theory describing the daily GPP, we speculated the relationship between RUE used in our study and that in describing the daily GPP, which aimed to clarify mechanisms underlying the approaches that factors affect the spatial variation of GPPyr.

$\mathrm{GPP}_{\mathrm{yr}}$ is also the product of growing-season mean GPP $\left(\mathrm{GPP}_{\mathrm{gs}}\right)$ and growing-season length (GSL), where $\mathrm{GPP}_{g s}$ may approximate to the product of growing-season mean RUE (RUEgs) and growing-season mean APAR (APARgs), which may approximate to the multiplication of growing-season mean FPAR (FPARgs) and growing-season mean PAR (PARgs) (Stoy et al., 2008). In addition, RUE is the results of maximum RUE (mRUE) multiplying the limiting effects of various factors and mRUE varies little among season (Monteith, 1972; Running et al., 2004). Therefore, GPP may approximate to the product of mRUE, FPAR gs $_{\text {, PAR }}, \mathrm{GSL}$, and limiting effects of various factors. Additionally, the seasonal variation of PAR was smaller than its spatial variation (Zhu et al., 2010), which may make the spatial variation of $\mathrm{PAR}_{\mathrm{gs}}$ be similar to that of $\mathrm{PAR}_{\mathrm{yr}}$. Meanwhile, growing-season LAI (LAIgs) dominated the LAI in sites used in this study, which may make the spatial variation of

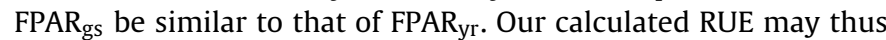
be proportional to the product of mRUE, GSL, and limiting effects of various factors.

Therefore, the effect of MAT on the spatial variation of RUE may be through the following two approaches. First, MAT, whose increases lengthened the GSL (Liu et al., 2010), dominated the spatial variation of GSL thus RUE. Second, the increasing MAT may smooth the limiting effect of $T_{a}$ thus improved RUE (Yuan et al., 2010). The effect of $\rho_{\text {cyr }}$ on RUE may be achieved through altering mRUE as the increase of $\rho_{\text {cyr }}$ supplied more substrate for photosynthesis and improved the carboxylation efficiency (Norby et al., 2005).

MAP dominated the spatial variation of LAI $_{\mathrm{yr}}$ (Supplementary Information 1), which was consistent with the model results (Shao and Zeng, 2011). Given that FPAR effect of MAP on the spatial variation of PPAR $_{\mathrm{yr}}$ was achieved through altering $\mathrm{LAI}_{\mathrm{yr}}$.

Additionally, our results may somewhat differ from previous studies focusing on the spatial variation of RUE (Garbulsky et al., 2010; Schwalm et al., 2006), which may primarily stem from the unique climate gradients of China as few Chinese sites were included in their studies (Garbulsky et al., 2010; Schwalm et al., 2006). 

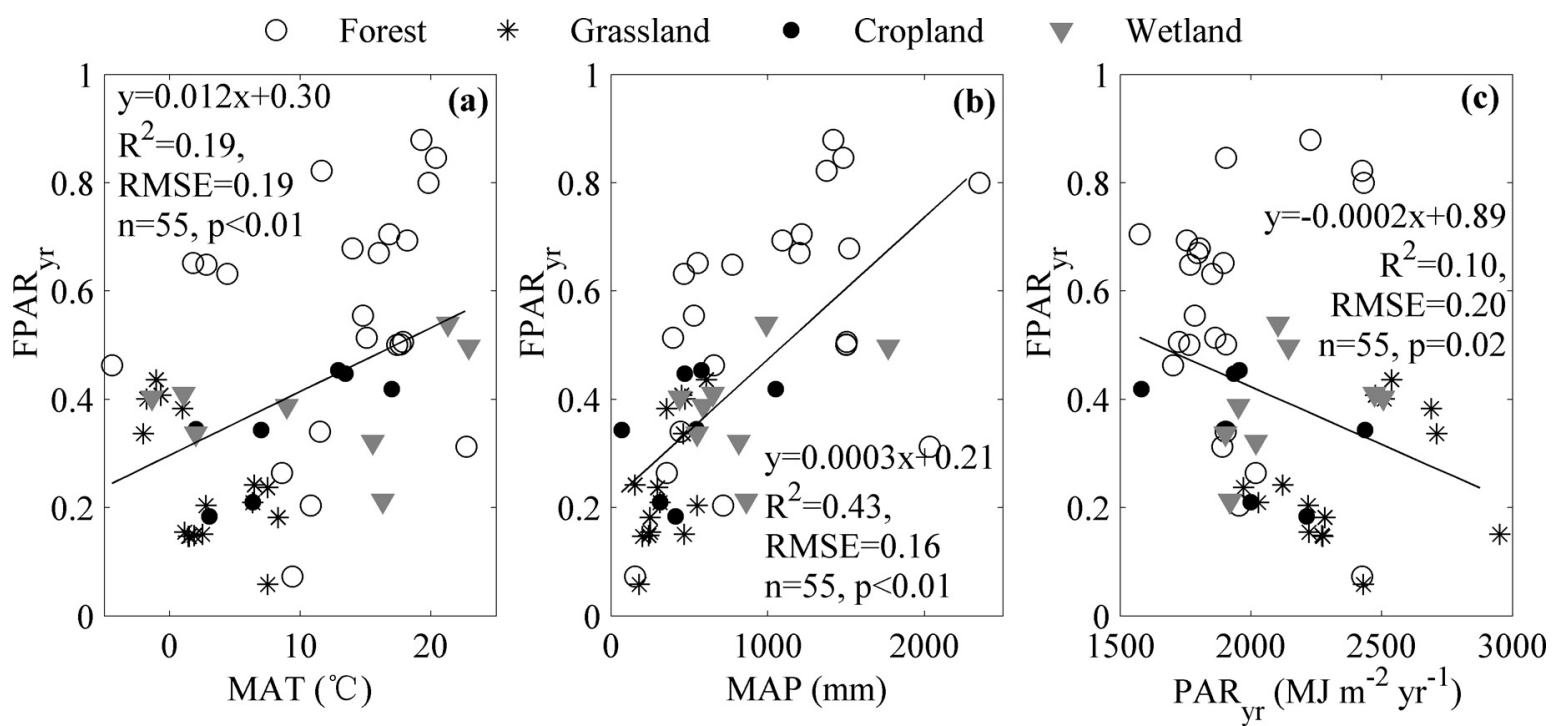

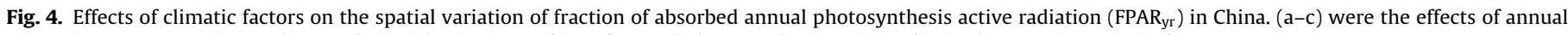
mean air temperature (MAT, a), annual precipitation (MAP, b), and annual photosynthesis active radiation $\left(\mathrm{PAR}_{\mathrm{yr}}, \mathrm{c}\right)$, respectively.

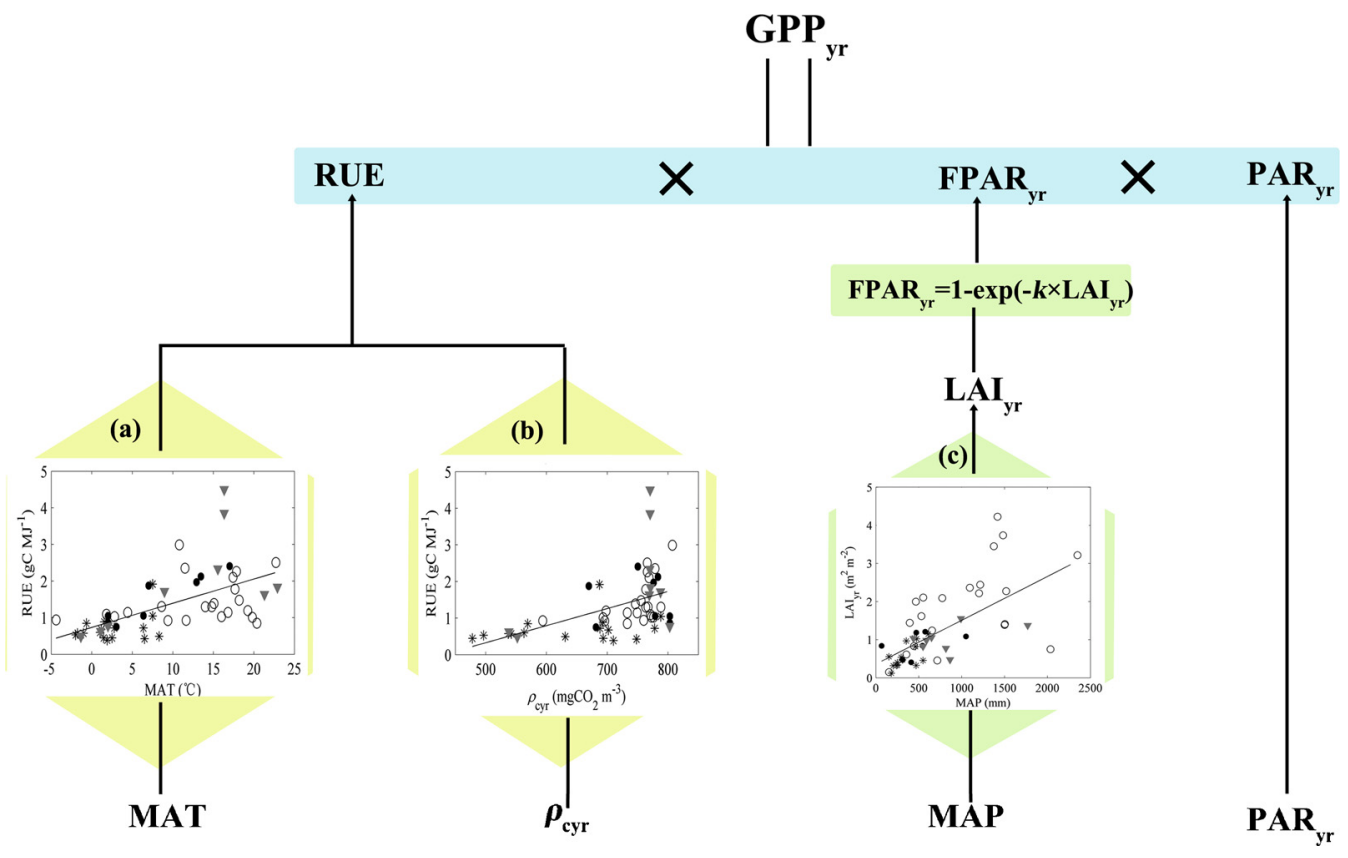

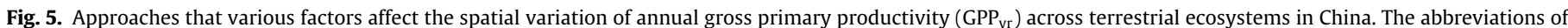

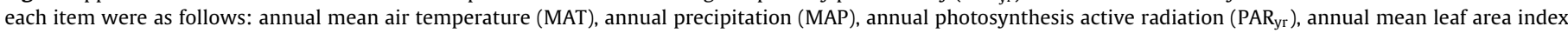

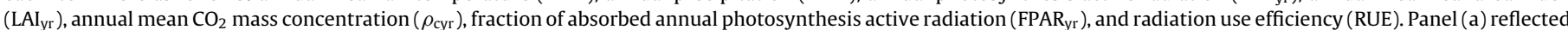

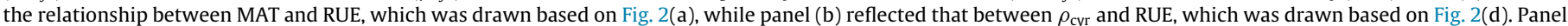
(c) reflected the relationship between MAP and $\mathrm{LAI}_{\mathrm{yr}}$, which was drawn based on the Supplementary Material 1.

\subsection{Uncertainties analyses}

In this study, we analyzed the approaches that climatic factors affect the spatial variation of $\mathrm{GPP}_{\mathrm{yr}}$ based on the radiation use efficiency theory. Our results not only validated the dominating role of climatic factors such as MAT and MAP (Kato and Tang, 2008; Yu et al., 2013) but also found the role of $\rho_{\text {cyr }}$ in the spatial variation of $\mathrm{GPP}_{\mathrm{yr}}$. Most importantly, we revealed how these climatic factors affect the spatial variation of GPPyr. Our results would therefore improve our understanding on the spatial variation of $\mathrm{GPP}_{\mathrm{yr}}$ and provide an alternative approach to the regional GPP $\mathrm{yr}_{\mathrm{r}}$ assessment.

However, there were some uncertainties in this study, which can be summarized into the following two aspects. First, the mechanisms underlying the approaches that factors affect the spatial variation of GPP $\mathrm{yr}_{\mathrm{r}}$ should be deeply investigated. Though we speculated how climatic factors affect the spatial variations of RUE and $\mathrm{FPAR}_{\mathrm{yr}}$ from the radiation use efficiency theory, we still needed more data especially daily data to support our speculation, such as $\mathrm{GPP}_{\mathrm{gs}}$ was proportional to the product of RUE and APAR gs, which would also benefit for revealing other potential factors affecting the spatial variation of RUE. Second, only using MAP to infer the spatial variation of $\mathrm{FPAR}_{\mathrm{yr}}$ was uncertain. Though MAP was found to be the direct factor affecting the spatial variation of $\mathrm{FPAR}_{\mathrm{yr}}$, there were many other factors such as human disturbance may

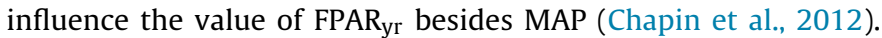
However, our analysis on the relationship between MAP and FPAR $\mathrm{Fr}_{\mathrm{yr}}$ 
primarily aimed to illustrate how MAP affects the spatial variation of GPPyr but not to infer PPAR $_{\mathrm{yr}}$ from MAP.

\section{Conclusions}

From the viewpoint of radiation use efficiency theory, we revealed how various factors affect the spatial variation of GPP through investigating the factors affecting the spatial variations of RUE and FPAR $\mathrm{R}_{\mathrm{yr}}$ based on network eddy covariance measurements. Results suggest that MAT and $\rho_{\text {cyr }}$ affected the spatial variation of GPP $\mathrm{yr}_{\mathrm{r}}$ primarily through altering RUE while the effect of MAP was achieved through altering FPAR $_{\mathrm{yr}}$. Our results improved our understanding on the spatial variation of GPP $\mathrm{yr}_{\mathrm{r}}$ and provided an alternative approach for regional carbon budget assessment.

\section{Acknowledgments}

This research was supported by the National Natural Science Foundation of China (31420103917, 31500390, 31290221, and 41501381), the CAS Strategic Priority Research Program (XDA05050601), and National Key Research and Development Program (2010CB833504). Special thanks to data provider from the FLUXNET community especially ChinaFLUX and USCCC networks. We gratefully acknowledge the reviewers for spending their valuable time to provide constructive comments.

\section{Appendix A. Supplementary Material}

Supplementary material associated with this article can be found, in the online version, at http://dx.doi.org/10.1016/j.ecolind. 2015.11.028.

\section{References}

Baldocchi, D., 2008. Breathing of the terrestrial biosphere: Lessons learned from a global network of carbon dioxide flux measurement systems. Aust. J. Bot. 56, $1-26$

Beer, C., Reichstein, M., Tomelleri, E., Ciais, P., Jung, M., Carvalhais, N., Rodenbeck, C., Arain, M.A., Baldocchi, D., Bonan, G.B., Bondeau, A., Cescatti, A., Lasslop, G., Lindroth, A., Lomas, M., Luyssaert, S., Margolis, H., Oleson, K.W., Roupsard, O., Veenendaal, E., Viovy, N., Williams, C., Woodward, F.I., Papale, D., 2010. Terrestrial gross carbon dioxide uptake: Global distribution and covariation with climate. Science 329, 834-838.

Chapin, F.S., Matson, P.A., Vitousek, P.M., 2012. Principles of Terrestrial Ecosystem Ecology, 2nd ed. Springer, New York, USA.

Chapin, F.S., Woodwell, G.M., Randerson, J.T., Rastetter, E.B., Lovett, G.M., Baldocchi, D.D., Clark, D.A., Harmon, M.E., Schimel, D.S., Valentini, R., Wirth, C., Aber, J.D., Cole, J.J., Goulden, M.L., Harden, J.W., Heimann, M., Howarth, R.W., Matson, P.A., McGuire, A.D., Melillo, J.M., Mooney, H.A., Neff, J.C., Houghton, R.A., Pace, M.L., Ryan, M.G., Running, S.W., Sala, O.E., Schlesinger, W.H., Schulze, E.D., 2006. Reconciling carbon-cycle concepts, terminology, and methods. Ecosystems 9, $1041-1050$

Chen, D., 2010. Dynamics and Controls of Carbon Exchange of a Tropical Montane Rain Forest at Jianfengling, China. Chinese Academy of Forestry, Beijing, PR China, pp. 139 (in Chinese with English abstract).

Chen, H., 2013. Carbon Sequestration, Litter Decomposition and Consumption in Two Subtropical Mangrove Ecosystems of China. Xiamen University, Xiamen, PR China, pp. 158 (in Chinese with English abstract).

Chen, J.M., Mo, G., Pisek, J., Liu, J., Deng, F., Ishizawa, M., Chan, D., 2012. Effects of foliage clumping on the estimation of global terrestrial gross primary productivity. Global Biogeochem. Cycles 26, GB1019.

Chen, S., Chen, J., Lin, G., Zhang, W., Miao, H., Wei, L., Huang, J., Han, X., 2009. Energy balance and partition in Inner Mongolia steppe ecosystems with different land use types. Agric. For. Meteorol. 149, 1800-1809.

Chen, W., Li, C., He, G., Wang, X., Zha, T., Jia, X., 2013a. Dynamics of $\mathrm{CO}_{2}$ exchange and its environmental controls in an urban green-land ecosystem in Beijing Olympic Forest Park. Acta Ecol. Sin. 33, 6712-6720 (In Chinese with English abstract).

Chen, Z., Yu, G., Ge, J., Sun, X., Hirano, T., Saigusa, N., Wang, Q., Zhu, X., Zhang, Y. Zhang, J., Yan, J., Wang, H., Zhao, L., Wang, Y., Shi, P., Zhao, F., 2013b. Temperature and precipitation control of the spatial variation of terrestrial ecosystem carbon exchange in the Asian region. Agric. For. Meteorol. 182-183, 266-276.

Ciais, P., Reichstein, M., Viovy, N., Granier, A., Ogee, J., Allard, V., Aubinet, M., Buchmann, N., Bernhofer, C., Carrara, A., Chevallier, F., De Noblet, N., Friend, A.D. Friedlingstein, P., Grunwald, T., Heinesch, B., Keronen, P., Knohl, A., Krinner, G., Loustau, D., Manca, G., Matteucci, G., Miglietta, F., Ourcival, J.M., Papale, D.,
Pilegaard, K., Rambal, S., Seufert, G., Soussana, J.F., Sanz, M.J., Schulze, E.D., Vesala, T., Valentini, R., 2005. Europe-wide reduction in primary productivity caused by the heat and drought in 2003. Nature 437, 529-533.

Ciais, P., Sabine, C., Bala, G., Bopp, L., Brovkin, V., Canadell, J., Chhabra, A., DeFries, R., Galloway, J., Heimann, M., Jones, C., Quéré, C.L., Myneni, R.B., Piao, S., Thornton, P., 2013. Carbon and Other Biogeochemical Cycles. In: Stocker, T.F., Qin, D., Plattner G.-K., Tignor, M., Allen, S.K., Boschung, J., Nauels, A., Xia, Y., Bex, V., Midgley, P.M. (Eds.), Climate Change 2013: The Physical Science Basis. Contribution of Working Group I to the Fifth Assessment Report of the Intergovernmental Pane on Climate Change. Cambridge University Press, Cambridge, United Kingdom and New York, NY, USA, pp. 465-570.

Dong, G., Guo, J., Chen, J., Sun, G., Gao, S., Hu, L., Wang, Y., 2011. Effects of spring drought on carbon sequestration, evapotranspiration and water use efficiency in the songnen meadow steppe in northeast China. Ecohydrology 4, 211-224.

Du, Q., Liu, H., Feng, J., Wang, L., Huang, J., Zhang, W., Bernhofer, C., 2012. Carbon dioxide exchange processes over the grassland ecosystems in semiarid areas of China. Sci. China Earth Sci. 55, 644-655.

Editorial Committee of Vegetation Map of China, 2007. Vegetation Map of the People's Republic of China (1:1 000 000). Geology Publishing House, Beijing, China.

Garbulsky, M.F., Peñuelas, J., Papale, D., Ardö, J., Goulden, M.L., Kiely, G., Richardson, A.D., Rotenberg, E., Veenendaal, E.M., Filella, I., 2010. Patterns and controls of the variability of radiation use efficiency and primary productivity across terrestrial ecosystems. Global Ecol. Biogeogr. 19, 253-267.

Geng, S., 2011. Study on the Carbon Flux Observation over Poplar Plantation Ecosystem of XiPing City in Henan Province of China. Beijing Forestry University, Beijing, PR China, pp. 91 (in Chinese with English abstract).

Guo, H., 2010a. Carbon Fluxes over an Estuarine Wetland: In Situ Measurement and Modeling. Fudan University, Shanghai, PR China, pp. 137 (in Chinese with English abstract).

Guo, L., 2010b. The Variations of Water Use Efficiency and Evapotranspiration over a Plantation in the Southern Part of Hilly Areas of North-China. Chinese Academy of Forestry, Beijing, PR China, pp. 76 (in Chinese with English abstract)

Han, S., 2008. Productivity Estimation of the Poplar Plantations on the Beaches in Middle and Low Reaches of Yangtze River Using Eddy Covariance Measurement. Chinese Academy of Forestry, Beijing, PR China, pp. 75 (in Chinese with English abstract).

Hao, Y.B., Cui, X.Y., Wang, Y.F., Mei, X.R., Kang, X.M., Wu, N., Luo, P., Zhu, D., 2011. Predominance of precipitation and temperature controls on ecosystem $\mathrm{CO}_{2}$ exchange in Zoige alpine wetlands of southwest China. Wetlands 31, 413-422.

Hilker, T., Coops, N.C., Wulder, M.A., Black, T.A., Guy, R.D., 2008. The use of remote sensing in light use efficiency based models of gross primary production: A review of current status and future requirements. Sci. Total Environ. 404, 411-423.

Houghton, R.A., 2007. Balancing the Global Carbon Budget. Annu. Rev. Earth Planet. Sci. 35, 313-347.

Kato, T., Tang, Y.H., 2008. Spatial variability and major controlling factors of $\mathrm{CO}_{2}$ sink strength in Asian terrestrial ecosystems: evidence from eddy covariance data. Global Change Biol. 14, 2333-2348.

Kato, T., Tang, Y.H., Gu, S., Hirota, M., Du, M.Y., Li, Y.N., Zhao, X.Q., 2006. Temperature and biomass influences on interannual changes in $\mathrm{CO}_{2}$ exchange in an alpine meadow on the Qinghai-Tibetan Plateau. Global Change Biol. 12, 1285-1298.

Keeling, C.D., Bacastow, R.B., Bainbridge, A.E., Ekdahl, C.A., Guenther, P.R., Waterman, L.S., Chin, J.F.S., 1976. Atmospheric carbon dioxide variations at Mauna Loa Observatory. Hawaii. Tellus 28, 538-551.

Law, B.E., Falge, E., Gu, L., Baldocchi, D.D., Bakwin, P., Berbigier, P., Davis, K., Dolman, A.J., Falk, M., Fuentes, J.D., Goldstein, A., Granier, A., Grelle, A., Hollinger, D., Janssens, I.A., Jarvis, P., Jensen, N.O., Katul, G., Mahli, Y., Matteucci, G., Meyers, T., Monson, R., Munger, W., Oechel, W., Olson, R., Pilegaard, K., Paw, K.T. Thorgeirsson, H., Valentini, R., Verma, S., Vesala, T., Wilson, K., Wofsy, S., 2002. Environmental controls over carbon dioxide and water vapor exchange of terrestrial vegetation. Agric. For. Meteorol. 113, 97-120.

Lei, H., Yang, D., 2010. Seasonal and interannual variations in carbon dioxide exchange over a cropland in the North China Plain. Global Change Biol. 16, 2944-2957.

Li, X., Liang, S., Yu, G., Yuan, W., Cheng, X., Xia, J., Zhao, T., Feng, J., Ma, Z., Ma, M., Liu, S. Chen, J., Shao, C., Li, S., Zhang, X., Zhang, Z., Chen, S., Ohta, T., Varlagin, A., Miyata A., Takagi, K., Saiqusa, N., Kato, T., 2013. Estimation of gross primary production over the terrestrial ecosystems in China. Ecol. Modell. 261-262, 80-92.

Liang, S., Zhao, X., Liu, S., Yuan, W., Cheng, X., Xiao, Z., Zhang, X., Liu, Q., Cheng, J. Tang, H., Qu, Y., Bo, Y., Qu, Y., Ren, H., Yu, K., Townshend, J., 2013. A long-term Global LAnd Surface Satellite (GLASS) data-set for environmental studies. Int. J. Digital Earth 6, 5-33.

Liu, B.H., Henderson, M., Zhang, Y.D., Xu, M., 2010. Spatiotemporal change in China's climatic growing season: 1955-2000. Clim. Change 99, 93-118.

Liu, R., Li, Y., Wang, Q.-X., 2012. Variations in water and $\mathrm{CO}_{2}$ fluxes over a saline desert in western China. Hydrol. Processes 26, 513-522.

Luyssaert, S., Inglima, I., Jung, M., Richardson, A.D., Reichsteins, M., Papale, D., Piao, S.L., Schulzes, E.D., Wingate, L., Matteucci, G., Aragao, L., Aubinet, M., Beers, C., Bernhoffer, C., Black, K.G., Bonal, D., Bonnefond, J.M., Chambers, J., Ciais, P., Cook, B., Davis, K.J., Dolman, A.J., Gielen, B., Goulden, M., Grace, J., Granier, A., Grelle, A. Griffis, T., Grunwald, T., Guidolotti, G., Hanson, P.J., Harding, R., Hollinger, D.Y., Hutyra, L.R., Kolar, P., Kruijt, B., Kutsch, W., Lagergren, F., Laurila, T., Law, B.E., Le Maire, G., Lindroth, A., Loustau, D., Malhi, Y., Mateus, J., Migliavacca, M., Misson, L., Montagnani, L., Moncrieff, J., Moors, E., Munger, J.W., Nikinmaa, E., Ollinger, S.V., Pita, G., Rebmann, C., Roupsard, O., Saigusa, N., Sanz, M.J., Seufert, G., Sierra, C., Smith, M.L., Tang, J., Valentini, R., Vesala, T., Janssens, I.A., 2007. $\mathrm{CO}_{2}$ balance 
of boreal, temperate, and tropical forests derived from a global database. Global Change Biol. 13, 2509-2537.

Magnani, F., Mencuccini, M., Borghetti, M., Berbigier, P., Berninger, F., Delzon, S., Grelle, A., Hari, P., Jarvis, P.G., Kolari, P., Kowalski, A.S., Lankreijer, H., Law, B.E., Lindroth, A., Loustau, D., Manca, G., Moncrieff, J.B., Rayment, M., Tedeschi, V., Valentini, R., Grace, J., 2007. The human footprint in the carbon cycle of temperate and boreal forests. Nature 447, 849-851.

Monteith, J.L., 1972. Solar radiation and productivity in tropical ecosystems. J. Appl. Ecol. 9, 747-766

Nemani, R.R., Keeling, C.D., Hashimoto, H., Jolly, W.M., Piper, S.C., Tucker, C.J., Myneni, R.B., Running, S.W., 2003. Climate-driven increases in global terrestrial net primary production from 1982 to 1999. Science 300, 1560-1563.

Norby, R.J., DeLucia, E.H., Gielen, B., Calfapietra, C., Giardina, C.P., King, J.S., Ledford, J., McCarthy, H.R., Moore, D.J.P., Ceulemans, R., De Angelis, P., Finzi, A.C., Karnosky, D.F., Kubiske, M.E., Lukac, M., Pregitzer, K.S., Scarascia-Mugnozza, G.E., Schlesinger, W.H., Oren, R., 2005. Forest response to elevated CO2 is conserved across a broad range of productivity. PNAS 102, 18052-18056.

Piao, S., Fang, J., Ciais, P., Peylin, P., Huang, Y., Sitch, S., Wang, T., 2009. The carbon balance of terrestrial ecosystems in China. Nature 458, 1009-1013.

Reichstein, M., Papale, D., Valentini, R., Aubinet, M., Bernhofer, C., Knohl, A., Laurila, T. Lindroth, A., Moors, E., Pilegaard, K., Seufert, G., 2007. Determinants of terrestrial ecosystem carbon balance inferred from European eddy covariance flux sites. Geophys. Res. Lett. 34, L01402.

Running, S.W., Nemani, R.R., Heinsch, F.A., Zhao, M., Reeves, M., Hashimoto, H., 2004 A continuous satellite-derived measure of global terrestrial primary production. Bioscience 54, 547-560.

Schwalm, C.R., Black, T.A., Arniro, B.D., Arain, M.A., Barr, A.G., Bourque, C.P.A., Dunn, A.L., Flanagan, L.B., Giasson, M.A., Lafleur, P.M., Margolis, H.A., McCaughey, J.H., Orchansky, A.L., Wofsy, S.C., 2006. Photosynthetic light use efficiency of three biomes across an east-west continental-scale transect in Canada. Agric. For. Meteorol. 140, 269-286.

Shao, P., Zeng, X., 2011. Spatiotemporal relationship of leaf area index simulated by CLM3.0-DGVM and climatic factors. Acta Ecol. Sin. 31, 4725-4731 (in Chinese with English abstract).

Song, T., 2007. Long Term Carbon Dioxide Flux Measurements in Sanjiang Plain, Northeastern China. Nanjing University of Information Science and Technology, Nanjing, PR China, pp. 187 (in Chinese with English abstract).

Stoy, P.C., Katul, G.G., Siqueira, M.B.S., Juang, J.Y., Novick, K.A., McCarthy, H.R., Oishi, A.C., Oren, R., 2008. Role of vegetation in determining carbon sequestration along ecological succession in the southeastern United States. Global Change Biol. 14, 1409-1427.

Sun, C., Jiang, H., Zhou, G., Yang, S., Chen, Y., 2013. Variation characteristics of CO flux in Phyllostachys edulis forest ecosystem in subtropical region of China. Chin. J. Appl. Ecol. 24, 2717-2724 (in Chinese with English abstract).

Sun, C., Wang, C., Shen, S., Zhang, J., 2012. Seasonal characteristics of $\mathrm{CO}_{2}$ fluxes above urban green space in the Pearl River Delta, China. Acta Ecol. Sin. 32, 1273-1282 (in Chinese with English abstract).

Tan, Z.-H., Zhang, Y.-P., Schaefer, D., Yu, G.-R., Liang, N., Song, Q.-H., 2011. An oldgrowth subtropical Asian evergreen forest as a large carbon sink. Atmos. Environ. $45,1548-1554$

Tang, X., Chen, W., Li, C., Zha, T., Wu, B., Wang, X., Jia, X., 2013. Net carbon exchange and its environmental affecting factors in a forest plantation in Badaling, Beijing of China. Chin. J. Appl. Ecol. 24, 3057-3064 (In Chinese with English Abstract).

Thoning, K.W., Tans, P.P., Komhyr, W.D., 1989. Atmospheric carbon dioxide at Mauna Loa Observatory: 2. Analysis of the NOAA GMCC data, 1974-1985. J. Geophys. Res.: Atmospheres 94, 8549-8565.

Wang, H.-m., Saigusa, N., Zu, Y.-g., Wang, W.-j., Yamamoto, S., Kondo, H., 2008a. Carbon fluxes and their response to environmental variables in a Dahurian larch forest ecosystem in northeast China. J. Forestry Res. 19, 1-10.

Wang, H., Jia, G., Fu, C., Feng, J., Zhao, T., Ma, Z., 2010. Deriving maximal light use efficiency from coordinated flux measurements and satellite data for regiona gross primary production modeling. Remote Sens. Environ. 114, 2248-2258.

Wang, X., Ma, M., Huang, G., Veroustraete, F., Zhang, Z., Song, Y., Tan, J., 2012. Vegetation primary production estimation at maize and alpine meadow over the Heihe River Basin, China. Int. J. Appl. Earth Obs. Geoinf. 17, 94-101.
Wang, X.C., 2008. Temporal Variations and Environmental Control of Carbon Dioxide Exchange of a Natural Secondary Forest in Northeastern China. Northeast Forestry University, Haerbin, PR China, pp. 72 (in Chinese with English abstract).

Wang, X.C., Wang, C.K., Yu, G.R., 2008b. Spatio-temporal patterns of forest carbon dioxide exchange based on global eddy covariance measurements. Sci. China Series D Earth Sci. 51, 1129-1143.

Wang, Y., Zhou, G., Wang, Y., 2008c. Environmental effects on net ecosystem CO2 exchange at half-hour and month scales over Stipa krylovii steppe in northern China. Agric. For. Meteorol. 148, 714-722.

Wu, C., Munger, J.W., Niu, Z., Kuang, D., 2010a. Comparison of multiple models for estimating gross primary production using MODIS and eddy covariance data in Harvard Forest. Remote Sens. Environ. 114, 2925-2939.

Wu, G.X., Liu, Y.M., Wang, T.M., Wan, R.J., Liu, X., Li, W.P., Wang, Z.Z., Zhang, Q., Duan, A.M., Liang, X.Y., 2007. The influence of mechanical and thermal forcing by the Tibetan Plateau on Asian climate. J. Hydrometeorol. 8, 770-789.

Wu, L., Gu, S., Zhao, L., Xu, S., Zhou, H., Feng, C., Xu, W., Li, Y., Zhao, X., Tang, Y., 2010 b. Variation in net $\mathrm{CO} 2$ exchange,gross primary production and its affecting factors in the planted pasture ecosystem in Sanjiangyuan Region of the Qinghai-Tibetan Plateau of China. Acta Phytoecol. Sin. 34, 770-780 (in Chinese with English abstract).

Xiao, J., Sun, G., Chen, J., Chen, H., Chen, S., Dong, G., Gao, S., Guo, H., Guo, J., Han, S. Kato, T., Li, Y., Lin, G., Lu, W., Ma, M., McNulty, S., Shao, C., Wang, X., Xie, X., Zhang, X., Zhang, Z., Zhao, B., Zhou, G., Zhou, J., 2013. Carbon fluxes, evapotranspiration, and water use efficiency of terrestrial ecosystems in China. Agric. For. Meteorol. $182-183,76-90$.

Yang, S., 2012. Characteristies of CO2 Flux in a Phyllostachys Edulis Ecosystems in Anji county, Zhejiang Province. Zhejiang Agricultural and Forestry University Hangzhou, PR China, pp. 54 (in Chinese with English abstract).

Yu, G.-R., Zhu, X.-J., Fu, Y.-L., He, H.-L., Wang, Q.-F., Wen, X.-F., Li, X.-R., Zhang, L.-M., Zhang, L., Su, W., Li, S.-G., Sun, X.-M., Zhang, Y.-P., Zhang, J.-H., Yan, J.-H., Wang, H.-M., Zhou, G.-S., Jia, B.-R., Xiang, W.-H., Li, Y.-N., Zhao, L., Wang, Y.-F., Shi, P.-L., Chen, S.-P., Xin, X.-P., Zhao, F.-H., Wang, Y.-Y., Tong C.-L., 2013. Spatial patterns and climate drivers of carbon fluxes in terrestrial ecosystems of China. Global Change Biol. 19, 798-810.

Yuan, W.P., Liu, S.G., Yu, G.R., Bonnefond, J.M., Chen, J.Q., Davis, K., Desai, A.R., Goldstein, A.H., Gianelle, D., Rossi, F., Suyker, A.E., Verma, S.B., 2010. Global estimates of evapotranspiration and gross primary production based on MODIS and global meteorology data. Remote Sens. Environ. 114, 1416-1431.

Zha, T.G., 2007. Carbon Balance of a Poplar Plantation Ecosystem in Daxing, Beijing Beijing Forestry University, Beijing, PR China, pp. 168 (in Chinese with English abstract).

Zhang, F., Li, Y., Cao, G., Li, F., Ye, G., Liu, J., Wei, Y., Zhao, X., 2012. CO2 fluxes and their driving factors over alpine meadow grassland ecosystems in the northern shore of Qinghai Lake, China. Chin. J. Plant Ecol. 36, 187-198 (in Chinese with English abstract).

Zhang L.P., 2010. Characteristics of CO2 Flux in a Chinese Fir Plantations Eeosystem in Huitong County, Hunan Province. Central South University of Forestry and Technology, Changsha, PR China, pp. 61 (in Chinese with English abstract).

Zhang, W.L., Chen, S.P., Chen, J., Wei, L., Han, X.G., Lin, G.H., 2007. Biophysical regulations of carbon fluxes of a steppe and a cultivated cropland in semiarid Inner Mongolia. Agric. For. Meteorol. 146, 216-229.

Zhang, Y.P., Tan, Z.H., Song, Q.H., Yu, G.R., Sun, X.M., 2010. Respiration controls the unexpected seasonal pattern of carbon flux in an Asian tropical rain forest. Atmos. Environ. 44, 3886-3893.

Zhao, M.S., Running, S.W., 2010. Drought-induced reduction in global terrestrial net primary production from 2000 through 2009. Science 329, 940-943.

Zhou, L., Zhou, G.S., Jia, Q.Y., 2009. Annual cycle of $\mathrm{CO}_{2}$ exchange over a reed (Phragmites australis) wetland in Northeast China. Aquat. Bot. 91, 91-98.

Zhu, X., He, H., Liu, M., Yu, G., Sun, X., Gao, Y., 2010. Spatio-temporal variation of photosynthetically active radiation in China in recent 50 years. J. Geog. Sci. 20, $803-817$.

Zhu, Y., 2005. Carbon Dioxide Exchange between Paddy Ecosystem and the Atmosphere in the Subtropical Region. Graduate University of Chinese Academy of Sciences, Beijing, PR China, pp. 118 (in Chinese with English abstract). 